\title{
Metáforas do novo coronavírus e da pandemia/COVID-19 em artigos de opinião publicados no Brasil $^{1}$
}

\section{Metaphors of the new coronavirus and COVID-19 pandemic in opinion articles published in Brazil}

\author{
A. Ariadne Domingues Almeida ${ }^{2}$ Elisângela Santana dos Santos ${ }^{3,}$ Neila Maria Oliveira Santana ${ }^{4}$
}

\begin{abstract}
Resumo
Apresentamos, neste texto, resultados de um estudo que teve por objetivo compreender como o coronavírus e a pandemia/COVID-19 são metaforicamente conceptualizados em artigos de opinião publicados em veículos de comunicação com ampla circulação no Brasil. Para isso, tomamos a Linguística Cognitiva como norte teórico. Assim sendo, traçamos diálogos com autores como Lakoff e Johnson (1980), Almeida e Santana (2019), Almeida e Santos (2019), Pérez (2018), entre outros. No que diz respeito à metodologia adotada para desenvolvimento da pesquisa empreendida, seguimos a abordagem qualitativa do objeto de estudo, dando-lhe um tratamento descritivo e interpretativo. Concluído o trabalho, verificamos que as conceptualizações postas em pauta foram estruturadas por metáforas, a exemplo de DOENÇA É GUERRA, DOENÇA É FENÔMENO NATURAL, VÍRUS É DIVINDADE, VÍRUS É SER VIVO.
\end{abstract}

Palavras-Chave: linguística cognitiva, metáfora, pandemia, coronavírus, COVID-19.

\begin{abstract}
In this paper, we present the results of a study that aimed to understand how the new coronavirus, the COVID-19 and the pandemic caused by the virus are metaphorically conceptualized in opinion articles published in wide circulation media in Brazil. For this purpose, this study takes Cognitive Linguistics as a theoretical guide and engages in dialog with authors such as Lakoff and Johnson (1980), Almeida e Santana (2019), Almeida e Santos (2019), Pérez (2018), among others. The methodology adopted follows a qualitative approach to provide a descriptive and interpretative treatment of the corpus under analysis. Once the analysis was concluded, we verified that the conceptualizations under study were structured by metaphors such as DISEASE IS WAR, DISEASE IS A NATURAL PHENOMENON, VIRUS IS A DEITY, and VIRUS IS A LIVING BEING.
\end{abstract}

Key Words: cognitive linguistics, methaphors, pandemic, coronavirus, COVID-19.

\footnotetext{
${ }^{1}$ Este artigo apresenta resultados da pesquisa que se desenvolve no âmbito do projeto intitulado "Conceptualização metafórica em discursos sobre o novo coronavírus", realizado por pesquisadores(as) da Universidade Federal da Bahia e da Universidade do Estado da Bahia.

${ }^{2}$ Professora Associada da Universidade Federal da Bahia (UFBA). Correo: ada.domingues@gmail.com. ORCID: https://orcid.org/0000-0002-9641-2530.

3 Professora Titular da Universidade do Estado da Bahia (UNEB). Correo: elssantos@uneb.br. ORCID: https://orcid.org/0000-0002-7869-3746.

${ }^{4}$ Professora Assistente da Universidade do Estado da Bahia (UNEB). Correo: nmosantana@uneb.br. ORCID: https://orcid.org/0000-0002-1767-2394.
} 


\section{Para iniciar}

Nos últimos meses do ano de 2019, na Ásia, pessoas começaram a ser contaminadas por um vírus até então desconhecido - o SARS-CoV-2 - e desenvolveram a COVID-195, doença que pode ocasionar nos humanos infectados tanto um quadro oligossintomático, isto é, com poucos sintomas, quanto pode gerar graves problemas respiratórios, podendo levá-los a óbito. Em 2020, esse vírus e, em consequência, essa doença chegaram à América do Sul e, particularmente no Brasil, já no segundo mês do corrente ano, começaram a ser registrados seus primeiros $\operatorname{casos}^{6}$. A doença pandêmica logo se espalhou por todo país, ocasionando alta mortandade, de modo que, em 29 de outubro desse mesmo ano, já tínhamos registrado 159.033 óbitos e 5.496 .402 casos diagnosticados ${ }^{7}$.

No Brasil, antes desses primeiros números da COVID-19 serem notificados, a imprensa já noticiava, no final do ano anterior, o problema e, daqui, acompanhávamos essa grave questão sanitária em outros continentes. Com seus primeiros registros, em São Paulo, foi se intensificando o papel da imprensa na cobertura da séria situação pandêmica externa e internamente. Com isso, não só notícias ou reportagens foram publicadas sobre a questão, mas também outros gêneros textuais passaram a ter o vírus, a doença, o seu enfrentamento e o seu tratamento como motivação para escrita. Entre esses gêneros, destacamos o artigo de opinião, porque esse foi o gênero dos textos que possibilitou a constituição do corpus do estudo, cujo objetivo principal foi compreender a conceptualização metafórica da pandemia causada pelo novo coronavírus.

Para alcançar seu primo objetivo, o referido estudo norteou-se por pressupostos teóricos da Linguística Cognitiva (doravante, LC), de sorte que propôs diálogos com autores como Lakoff e Johnson (1980), Almeida e Santana (2019), Almeida e Santos (2019), Pérez (2018), entre outros. Para o tratamento desse corpus, adotamos a perspectiva metodológica qualitativa do fazer científico e realizamos, a partir de uma abordagem exploratória, a descrição e a interpretação do fenômeno posto em pauta. Para apresentar os resultados alcançados com o desenvolvimento da pesquisa empreendida, este texto constitui-se de três seções, além destas Palavras Iniciais, das Considerações Finais e das Referências que alicerçaram as discussões. Isso posto, a seguir, passamos a apresentar o marco teórico que subsidiou o estudo do corpus.

\section{Bases teóricas para o estudo do significado e da metáfora em perspectiva cognitiva}

Entender como ocorre a construção do significado e sua importância para a linguagem, considerando o estabelecimento efetivo e eficaz do ato de comunicar, foi uma inquietação recorrente de filósofos, pensadores e estudiosos da linguagem do passado e ainda continua sendo no presente. E, apesar de questões sobre o fenômeno da significação terem sido postas desde a Antiguidade Clássica, é mais prudente afirmar que, apenas em meados do século XIX, com a

\footnotetext{
${ }^{5}$ COVID-19 é uma sigla que se desdobra em Coronavirus Disease - Doença do Coronavírus, somada a 19, indicativo do ano, quando ocorre a divulgação dos primeiros casos da doença na China. Disponível em: Por que o novo vírus recebeu o nome de Covid-19? (fiocruz.br) Acesso em: 11 de nov. de 2021.

6 O primeiro caso de COVID-19 no Brasil foi registrado em fevereiro deste ano. Disponível em https://g1.globo.com/sp/sao-paulo/noticia/2020/08/26/primeiro-caso-confirmado-de-covid-19-no-brasil-ocorreu-emsp-e-completa-seis-meses-nesta-quarta.ghtml Acesso em: 23 out. 2020.

${ }^{7}$ Disponível em https://g1.globo.com/bemestar/coronavirus/noticia/2020/10/29/casos-e-mortes-por-coronavirus-nobrasil-em-29-de-outubro-segundo-consorcio-de-veiculos-de-imprensa.ghtml Acesso em: 29 out. 2020.
} 
publicação da obra Essai de Sémantique, Science des Significations, do linguista Michel Bréal, em 1897, postulou-se uma ciência da significação propriamente dita, a Semântica. Esse autor, além de enfatizar a importância de se adotar uma perspectiva histórica para a averiguação de fenômenos atinentes à construção de sentidos, destacou a importância de se levar em conta a subjetividade e a cultura para o novo estudo proposto, enfatizando a prevalência do que está subjacente aos usos das palavras e expressões, em detrimento da descrição de aspectos formais ou de uma relação entre o significante e o seu referente, fundando, assim, as bases para os estudos semânticos que se desenvolveriam com mais vigor quase um século mais tarde.

Ainda que tenha sido posto à margem por teorias formalistas que se destacaram na primeira metade do século $\mathrm{XX}$, o estudo da significação tem seu valor reivindicado por um grupo de estadunidenses, formado por pesquisadores, como George Lakoff, Ronald Langacker, Mark Johnson, Leonard Talmy, entre outros, que, nas décadas finais dessa centúria, se opuseram ao modelo teórico gerativista, então predominante, com foco na sintaxe, e propuseram uma teoria semantocêntrica centrada no uso. Assim, as bases da LC nascem em meio à eclosão de um conflito epistemológico que despontava naquele momento e que tinha por objetivo, entre outras coisas, discutir o funcionamento dos mecanismos da mente humana e, também, a inter-relação entre os ambientes bio-psíquico-cognitivo e o geo-sócio-histórico-político-ideológico-cultural na construção da linguagem.

O novo modelo teórico, ao estudar a interação entre as diferentes dimensões da vida humana, visando à compreensão de como se dá a construção de sentidos, busca integrar domínios científicos diversos para compreender e explicar aquilo que está subjacente ao significado, trazendo imbricado à sua concepção (multi)interdisciplinar um olhar diferenciado sobre o que é e em que implica significar. Desse modo, o significado, até então considerado controverso e indefinido por teóricos de correntes formalistas, passa a ser entendido como natural, perspectivista, baseado no uso, de caráter enciclopédico e resultante de interações sensório-motoras, o que evidencia a sua natureza perceptual, corporificada, experiencial e situada. Tal concepção teórica adotada neste artigo, 40 anos depois da publicação de Methaphors We Live By, de Lakoff e Johnson (1980), marco teórico inaugural da LC, em certa medida, já havia sido prenunciada um século antes por Michel Bréal (1897) e mesmo por Aristóteles, como chama a atenção Umberto Eco (2013).

Assim, de acordo com a abordagem cognitivista da linguagem, a construção do significado é resultante de processos bio-psíquico-cognitivos, geo-sócio-histórico-cultural-políticoideológicos, somados às dimensões pragmático-discursivo-interacionais, uma vez que, diferente dos modelos de estudo formalistas que entendem a mente como uma entidade autônoma ou não corporificada, a LC parte da noção de "mente corpórea", baseada no Experiencialismo de Lakoff e Johnson (1980; 1999), para discutir a capacidade de o ser humano conceptualizar. Além disso, para esse modelo teórico, o significado é entendido como conceptualização, ou seja, como uma perspectivação a partir daquilo que o sujeito conceptualizador vivencia, experiencia e da maneira como interage com o mundo e com os seres à sua volta, por meio da sua mente corporificada, percebendo sua realidade e organizando-a em categorias, que decorrem da sua capacidade de categorizar, isto é, de re-organizar on-line o seu mundo interno-externo, conforme discute Almeida (2018). 
Tal como atesta Batoréo (2000),

[S]egundo os cognitivistas, o significado não se baseia na sua referencialidade do real, mas na experiência humana do mundo exterior. O mundo real influencia de facto a nossa vida mas apenas no modo como delimita o nosso sistema cognitivo. No entanto, este papel é desempenhado apenas pela nossa experiência, que, por um lado, varia conforme a cultura e, por outro, permite a interpretação de uma experiência em termos de outras, o que constrói significados metafóricos. As partes da realidade incompreensível e desconhecida são descobertas e ordenadas através da metáfora. (p. 138)

Em face desta nova compreensão cognitiva da linguagem, estudos que enfocam fenômenos do significado que antes eram obliterados ou marginalizados ou mesmo enfocados sob as perspectivas descritiva e formal, passaram a contar com contribuições funcionalistas, sendo abordados em uma perspectiva holística, uma vez que são consideradas a interação e a interdependência entre mente-corpo/indivíduo-sociedade. Para este estudo, interessarão as questões relativas à percepção da metáfora como fenômeno cognitivo, basilar para a compreensão de como o novo coronavírus e a pandemia/COVID-19 podem ser conceptualizados e categorizados.

A metáfora, embora seja um mecanismo de conceptualização e também de categorização, é um fenômeno que pode ser entendido como um processo de comparação ou recurso estilístico utilizado apenas nos textos literários e como um desvio de usos do léxico de uma língua. Essa compreensão advém da tradição dos estudos clássicos da Retórica e remonta à Antiguidade Clássica, tendo sido produzida uma ampla e diversificada literatura que a tem como objeto de suas reflexões. $\mathrm{Na}$ atualidade, ainda que a metáfora seja enfocada sob diferentes perspectivas, tem ocupado um lugar de destaque no campo dos estudos semânticos, constituindo-se em um dos principais objetos de investigação da LC. Com a implementação e desenvolvimento desse campo do saber, passa-se a pensar sobre como a metáfora atua no sistema conceptual e como age, a partir da inter-relação mente-corpo-linguagem, para compreensão da vida nas diferentes interações das quais a espécie humana participa.

Sendo um fenômeno da estrutura conceptual, a metáfora, porém, acha-se presente para além da literatura, de modo que pode ser encontrada em textos de variados domínios discursivos, a exemplo do jornalístico, publicitário, científico, registrando-se em toda linguagem corrente do nosso cotidiano, inclusive, sem se limitar à verbal. Desta forma, faz-se oportuno ressaltar que, como se trata de esquemas abstratos do pensamento, as metáforas se atualizam não apenas nas manifestações linguísticas, pois ocorrem, também, na linguagem artística, por meio da música, da dança, do desenho, da pintura, entre outras expressões da arte, bem como em objetos que fazem parte do nosso dia a dia. Ademais, podem se apresentar não somente em textos monomodais como também em multimodais, uma vez que ocorrem na tessitura de modos semióticos distintos, como demonstra Forceville (2009).

Iste posto, vale acrescentar que o ser humano organiza o seu conhecimento em diferentes domínios cognitivos e, por meio de metáforas, estrutura conceitos gerados a partir daquilo que experiencia, como anteriormente já assinalado. A metáfora, por sua parte, possibilita que um conceito possa ser compreendido, parcialmente, em termos de outro. Esse mapeamento pode ser representado pela notação X É (PARCIALMENTE) Y ou DOMÍNIO-ALVO É 
(PARCIALMENTE) DOMÍNIO-FONTE, uma vez que nem todos os elementos de um domíniofonte são projetados no domínio-alvo, como destacam Almeida e Santos (2020) e Barcelona (2009[1996]). A partir de um domínio-fonte, mais próximo da experiência física, mais tangencial e mais conhecido, compreendemos um domínio-alvo, mais aproximado das experiências emocionais, psíquicas, e, portanto, mais nocional e menos conhecido. Em linhas gerais, o domínioalvo herda a estrutura conceptual do domínio-fonte, que é perspectivado parcialmente, considerando-se o contexto geo-sócio-histórico-político-ideológico-cultural da significação e a condição bio-psíquica-cognitiva da espécie humana.

Em face desse mecanismo, é possível entender, por exemplo, que um vírus afete um sistema computacional, ou que outro afete a malha social; essas conceptualizações metafóricas são construções decorrentes do conhecimento de mundo dos seres humanos sobre a existência de microrganismos que podem atacar o seu próprio sistema imunológico e causar consequências que variam desde uma enfermidade simples, como uma gripe sem maiores sintomas, a uma enfermidade mais complexa com um risco de letalidade, como ocorre, em alguns casos, com a COVID-19. Esse entendimento é possível, porque os sujeitos conceptualizadores, ao compreenderem em termos de um vírus problemas que podem atingir, de forma destrutiva, o sistema operacional de um computador, a exemplo de um malware ${ }^{8}$, ou um ato de corrupção que pode afetar a estabilidade de uma sociedade, partem de um conhecimento de mundo físicoexperiencial, vivenciado desde épocas mais remotas, o qual é projetado nos domínios da tecnologia da computação/informação e social.

Por meio dessas projeções, é possível fazermos inferências ou acarretamentos que são mapeamentos adicionais, que viabilizam entender que o vírus de computador e o vírus da corrupção podem causar tantos danos aos sistemas computacional e social, respectivamente, quanto um vírus que afeta um sistema orgânico. Assim, tal como destacou Santos (2020), é possível inferir, a partir das metáforas MALWARE É VÍRUS e CORRUPÇÃO É VÍRUS, que um malware age como um organismo que pode causar problemas, danos e até a destruição dos dados de uma máquina, bem como um comportamento corrupto pode causar o enfraquecimento ou a aniquilação da crença nas autoridades políticas que estão em postos do poder, ocupando espaços sociais e que são contaminadas pelo "vírus da corrupção", agindo tal como os patógenos virais no corpo humano. Além disso, ocorrem outras inferências, como sociedade é um doente, computador é um paciente.

Como exemplo do que foi exposto sobre a metáfora do vírus do computador, trazemos o seguinte trecho coletado de um artigo 9 :

Odiado por todos, o Vírus de Computador é o inimigo número um de todos que possuem um desktop, notebook, tablet e até mesmo smartphone. [...] O Vírus é um software desenvolvido com base em características diversas e com inúmeros "temas". É chamado por muitos de software malicioso, tal qual um vírus que infecta o sistema e se espalha para outros computadores de forma muito rápida, através de links, e-mails e arquivos infectados. (Grifos em negrito, do autor e, em itálico, nossos).

\footnotetext{
${ }^{8}$ Termo para nomear qualquer tipo de malicious software que se infiltra em um dispositivo, causando-lhe danos.

${ }^{9}$ Disponível em Vírus de computador - Informática - InfoEscola Acesso em: 27 de out. de 2020.
} 
Já em relação à metáfora do vírus da corrupção, transcrevemos a seguinte passagem ${ }^{10}$ :

O vírus da corrupção atinge a todos, mas as principais vítimas são aquelas que mais dependem dos recursos públicos. [...] Para este mal existem vacinas, mas - assim como tantos outros vírus- é passível de mutações. A todo momento, ele encontra novas formas de burlar os Tribunais de Contas, forjar dados, direcionar editais e uma gama de outras ações capazes de corromper o sistema, atingindo a todos os contribuintes. (Grifos nossos).

Como podemos perceber, tais mapeamentos metafóricos revelam a importância que as metáforas têm na compreensão ideológica da realidade. As metáforas do vírus em termos de corruptor e de invasor de sistemas computacionais fazem parte da cultura ocidental e revelam aspectos da história da tecnologia no tempo presente, portanto são metáforas historicamente situadas. Conforme defende Pérez (2018),

[...] uma vez que certa visão de um processo histórico se fixou em um sintagma metafórico, e este circula nos discursos como única forma de ser compreendido e nomeado, então, será difícil transmitir outra visão desse mesmo fenômeno, já que, como disseram anteriormente Lakoff e Johnson, 'quem consegue impor suas metáforas impõe sua verdade' ${ }^{11}$. (p. 57)

Em síntese, as metáforas estão presentes nos pensamentos, nas ações e na linguagem humana, seja em textos verbais ou verbo-pictóricos, gerando sentidos por e para os sujeitos conceptualizadores no tempo e no espaço, através da inter-relação entre as dimensões biológicas e sócio-culturais produtoras de políticas e ideologias que emergem por meio das expressões metafóricas nas nossas interações discursivas, como explicitaram Almeida e Santos (2019). Após a exposição do aporte teórico que alicerçou o estudo do corpus, aduz-se, a seguir, o arcabouço metodológico que possibilitou chegar aos resultados a seguir expostos.

\section{Percurso metodológico}

Para realizar as discussões que serão aduzidas na terceira seção deste texto, foram selecionados ${ }^{12}$ 12 artigos de opinião, publicados entre os meses de março a setembro de 2020, quais sejam: 1) Coronavírus, desigualdade e indiferença; 2) $O$ último desserviço de Bolsonaro à nação; 3) $O$ vírus somos nós (ou uma parte de nós); 4) O futuro pós-coronavírus já está em disputa; 5) O Brasil está matando o Brasil; 6) O nojo; 7) Brasil sofre de fetiche da farda; 8) Tirem os joelhos brancos dos pescoços negros; 9) Os manifestos estão brancos demais; 10) A marcha dos mortos; 11) 7 de Setembro: morte; 12) Os humanos que o vírus descobriu no Brasil. Os dois primeiros foram postos

\footnotetext{
${ }^{10}$ Disponível em O vírus da corrupção (republicanos10.org.br) Acesso em: 27 de out. de 2020.

${ }^{11}$ No original: una vez que cierta visión de un proceso histórico se ha fijado en un sintagma metafórico, y éste circula en los discursos como única forma de ser comprendido y nombrado, entonces será difícil transmitir otra visión de ese mismo fenómeno ya que, como han dicho tempranamente Lakoff y Johnson, "quien logra imponer sus metáforas impone su verdad.

12 Foram selecionados aqueles artigos que apresentavam expressões metafóricas das conceptualizações estudadas, conforme critérios indicados nesta seção metodológica.
} 
em circulação pelo site $U O L$ - Universo Online - e os demais foram publicados no jornal El País - Brasil ${ }^{13}$.

No que concerne ao número de artigos selecionados para a constituição do corpus, cabe observarmos, com base em Almeida (2020), que a seleção do material textual a ser estudado se deu a partir de alguns contributos da Teoria dos Fractais. Assim sendo, optamos por selecionar os textos a partir da perspectiva da qualidade, em detrimento da quantidade, isto porque compreendemos que qualquer fenômeno linguageiro possui padrões de organização que se farão presentes em amostra de uso da linguagem, sejam menores ou maiores, já que entendemos, como Morin (2009[1999]), que a parte está no todo e o todo está na parte, conforme o princípio hologrâmico da Teoria da Complexidade.

Em vista disso, postulamos que o tamanho do corpus não deve ser a maior preocupação dos investigadores. Para tanto, adotamos a técnica da saturação, ao constatarmos a repetição de padrões metafóricos (Almeida e Santana, 2019). Neste estudo, a saturação, ou seja, a ausência de dados novos, mais especificamente, de padrões semânticos metafóricos acionados para a conceptualização em pauta, ocorreu no décimo segundo texto; daí, foi feito o corte na coleta e assim o corpus foi constituído. Na sequência, tecemos algumas considerações acerca da escolha do fenômeno em pauta, do arcabouço teórico eleito para sustentar o estudo do corpus e, finalmente, explanamos a propósito do norte que guiou a seleção do gênero eleito para coletar as expressões metafóricas estudadas.

No tocante à delimitação do fenômeno, consideramos, entre outras possibilidades para o estabelecimento do objeto de estudo, a necessidade premente de buscar entender como está sendo compreendido este grave problema de saúde que aflige, nos dias de hoje, a humanidade, desestabilizando a economia de países, agravando o estado de pobreza de alguns povos e/ou de determinados grupos sociais, privando crianças do convívio escolar, e, sobretudo, ceifando vidas por distintos cantos do planeta.

Diante da urgência de pensar sobre essa doença e sobre como tem sido tratada, ponderamos que a LC configura-se como um aporte seguro para produzir conhecimentos sobre a linguagem da pandemia; assim sendo, postulamos que esse campo do saber pode colaborar para o enfrentamento desse problema, ao possibilitar que demonstremos, através dos resultados de pesquisas alicerçados em seus pressupostos, como o ser humano pensa e age; isso pode, definitivamente, contribuir para a tomada de decisões e/ou para o entendimento sobre a ausência de ações efetivas no combate ao vírus, ou ainda para entender o aceite por parte da população de comportamentos duvidosos de autoridades políticas, quanto ao tratamento da pandemia, no que se refere, por exemplo, aos cortes na jornada de trabalho/salários, a não contestação ao atraso da compra de vacinas, entre outros casos.

Já no que concerne ao gênero selecionado para constituição do corpus do estudo, escolhemos o artigo de opinião, uma vez que é a materialização argumentativa da perspectiva do seu autor ou sua autora sobre o assunto e pode nos dar pistas importantes para alcançarmos uma compreensão mais aproximada de como ocorre essa conceptualização e, por conseguinte, pode possibilitar o entendimento de ações tomadas no âmbito desta séria crise sanitária.

${ }^{13}$ Vale observar que, inicialmente, apenas foram localizados dois artigos de opinião no UOL, documentando as conceptualizações metafóricas postas em pauta, por isto, decidiu-se ampliar a busca para outro veículo de comunicação, tendo sido selecionado o periódico EL País. 
Delimitado o objeto de estudo, assegurada a LC como base teórica e determinado o gênero dos textos que forneceriam as expressões linguísticas para a constituição do corpus, foi feita, como já anteriormente aqui sinalizado, uma abordagem qualitativa da metáfora, com base na interpretação das expressões linguísticas coletadas do citado corpus. Também, foi feita uma abordagem exploratória do referido fenômeno, além do seu tratamento descritivo e interpretativo, tendo sido o estudo fundamentado em uma revisão da literatura elaborada a partir de teóricos da LC, como posto na segunda seção deste texto. Além disso, toda a discussão ancorada a partir do corpus pautou-se em exemplos de uso reais que circulam socialmente no Brasil, através de veículos de imprensa do país.

A respeito dos procedimentos metodológicos, foram dados os seguintes passos para chegarmos aos resultados a serem aqui apresentados. Inicialmente, para selecionar os artigos antes citados, foi utilizada a ferramenta de busca dos referidos veículos de comunicação, tendo sido feita a procura pela sigla COVID-19 e pelos seguintes itens léxicos: vírus, coronavírus e pandemia. Localizados os textos, foi realizada a leitura de cada um dos artigos de opinião em sua íntegra, a fim de identificar, através da introspecção das pesquisadoras, as expressões linguísticas que instanciam as metáforas subjacentes à construção do discurso constante desses textos e, em consequência disso, viabilizadoras da linguagem que atesta diferentes conceptualizações de PANDEMIA, COVID-19, VÍRUS e CORONAVÍRUS. Dito isto, fica patente que o enfoque é feito na conceptualização de quatro conceitos distintos, mas inter-relacionados semanticamente, já que são elaborados a partir de experiência compartilhada nos dias hodiernos em todo Brasil.

Uma vez realizada essa identificação, as expressões linguísticas coletadas nos artigos foram organizadas, a partir do domínio-fonte acionado. Esses exemplos foram colocados em ordem de aparecimento nos textos, tendo sido utilizada a ordem numérica crescente para sua apresentação. Na sequência, entre parênteses, foi indicado o veículo de comunicação no qual foi publicado o artigo de opinião de onde a expressão linguística foi coletada e a data de publicação (p. ex.: El País, 25/03/2020). Além disso, seguindo a notação adotada em LC, os domínios-fonte (p. ex.: GUERRA) e as metáforas propostas foram grafadas em versalete (p. ex.: DOENÇA É GUERRA), enquanto as expressões metafóricas foram postas em itálico (p. ex.: "combate à pandemia"). Depois, foi feita a proposição das metáforas e, finalmente, foi realizada a apresentação dos resultados e a discussão sobre a conceptualização metafórica, que segue na próxima seção.

\section{Estudo do corpus}

Com a apreciação do corpus, verificamos que o domínio-fonte predominante para a conceptualização em pauta é o da GUERRA, embora outros domínios tenham sido encontrados, a saber: SOBRENATURAL, NATUREZA, ESPAÇO-TEMPO e ESPAÇO. Assim sendo, foram feitas projeções, isto é, inferências que foram mapeadas desses domínios para PANDEMIA, CORONA(VÍRUS) e COVID-19.

No que concerne ao primeiro domínio-fonte antes assinalado, algumas discussões têm sido realizadas acerca da chamada metáfora da guerra; isto porque expressões linguísticas resultantes de metáforas que recorrem a esse domínio têm sido, atualmente, bastante discutidas, tanto em estudos sobre a conceptualização da pandemia e do novo coronavírus, quanto em textos do domínio discursivo jornalístico, como ocorre no estudo de Bezerra Ferreira (2019). 
Recorrer a tal domínio é uma forma produtiva de gerar metáforas para tratar de doenças, conforme revelam estudos de Vanin (2016) e Almeida (2020). Desse modo, enfermidades são entendidas geralmente como um inimigo que precisa ser vencido pelo ser humano. Em vista disso, a noção de doença em termos de guerra passou a ser acionada frequentemente e evidenciada na forma como pacientes e os que estão em seu entorno, a exemplo de amigos e de parentes, se referem a problemas de saúde, como a tuberculose, a AIDS, o câncer e, atualmente, a COVID-19.

As noções de luta e de combate entre o ser humano e o Sars-Cov-2 surgem entre as expressões coletadas em artigos de opinião, tendo, assim, se mostrado recorrentes no corpus. Os usos linguísticos destacados nos trechos que seguem instanciam a metáfora DOENÇA É GUERRA, viabilizando inferir PANDEMIA/COVID-19 É INIMIGO. Entendemos que o conceito de pandemia compreende o modo de manifestação de uma doença infectocontagiosa que atinge diferentes pessoas em distintas regiões do planeta, devido à sua ampla disseminação, em um pequeno lapso de tempo. Então, por ser a COVID-19 uma pandemia, decidimos apresentar os resultados atinentes às conceptualizações de PANDEMIA e de COVID-19 juntos, pois acham-se em relação de inclusão semântica, uma vez que COVID-19 é uma doença pandêmica, como aqui já assinalado e se mostra em (01) al (10):

(01) "A forma como vivemos neste planeta nos tornou vítimas de pandemias". (El País, 25/03/2020)

(02) "Enfrentar uma pandemia num país em que desigualdade e pobreza extrema aumentaram nos últimos anos pelas políticas neoliberais é um imenso desafio". ( $E l$ País, 08/04/2020)

(03) "Não vejo no mundo um país mais desafiado que o Brasil. Precisa lutar contra uma pandemia com um perverso no poder que contraria todas as leis sanitárias [...]". (El País, 27/05/2020)

(04) "Não será possível vencer nem a pandemia nem a crise climática". (El País, $02 / 06 / 2020$ )

(05) "É isso que os movimentos de rua estão mostrando, desde as campanhas de solidariedade e combate à pandemia, na base do "nós por nós" [...]". (El País, $10 / 06 / 2020)$

(06) "Deixou a covid-19 avançar e agiu para reter recursos públicos destinados ao enfrentamento da doença [...]”. (El País, 03/09/2020)

(07) "No mês passado, o Datafolha mostrou que nove entre cada dez brasileiros pretendiam tomar a vacina contra a covid-19 tão logo ela fosse aprovada". (UOL, 03/09/2020)

(08) "O outro é a ação deliberada de Jair Bolsonaro e de pessoas, militares e civis, que ocupam cargos no seu Governo para, por um lado, deixar a covid-19 avançar e matar, por outro ampliar as condições para que ela mate mais". (El País, 16/09/2020) 
Outra inferência decorrente da metáfora DOENÇA É GUERRA é (CORONA)VÍRUS É INIMIGO, isto porque o domínio-fonte GUERRA tem diferentes elementos mapeados para o domínio-alvo (CORONA)VÍRUS e, nesse caso específico, o mapeamento possibilita a compreensão do novo vírus em termos de um inimigo, conforme as seguintes passagens (09-11) coletadas de alguns artigos:

(09) "Mas também ele se aproxima da ideia de uma outra sociedade possível no pósguerra pandêmica: "O vírus não vencerá o capitalismo”. (El País, 25/03/2020)

(10) "Lutar pela vida ameaçada pelo vírus é o imperativo da emergência”. (El País, 08/04/2020)

(11) "Neste momento, por mais que os demais países promovam ações de controle e fechem suas fronteiras, sem conter o novo coronavírus num país com 210 milhões de habitantes será muito difícil controlar a pandemia no planeta". (El País, $13 / 05 / 2020)$

Por fim, as últimas inferências decorrentes da metáfora referida são: VÍRUS É MUNIÇÃO e COVID-19 É MUNIÇÃO:

(12) "Enquanto o vírus atinge o corpo dos indígenas, o corpo da floresta é destruído pelas motosserras". (El País, 07/05/2020)

(13) "Um é a covid-19, que aqui atingiu proporções de catástrofe, tornando o Brasil um dos países mais afetados do mundo". (El País, 16/09/2020)

Os exemplos mostram que itens lexicais, como vítima, enfrentar, lutar, vencer, combater, atingir, conter, avançar, matar acionam sentidos que construímos a respeito da pandemia, do (corona)vírus e da COVID-19 como elementos de uma guerra. Mesmo que nós nunca tenhamos vivido batalhas e lutas nem tenhamos uma experiência bélica, ao menos prototípica, nós adquirimos esse conhecimento indiretamente através da televisão, do cinema, dos livros de história e de literatura. Sendo assim, parte do conhecimento que temos sobre guerra é projetado metaforicamente no domínio PANDEMIA de COVID-19 para que a compreendamos como tal.

Além do domínio GUERRA, é possível verificar o acionamento do domínio SOBRENATURAL para conceptualizar o coronavírus. É bem provável que essa associação advenha do nosso conhecimento religioso de que um deus é um ser sobrenatural. Seres humanos tendem a buscar estabelecer uma relação próxima com o divino, mesmo que esse não se apresente de forma palpável. A veneração ao sobrenatural, de alguma maneira, acompanha a humanidade, seja por um deus ou por deuses, de modo que é/são compreendido(s) como divindade(s):

(14) "No princípio era o vírus. Coronavírus. Em menos de dois meses após a primeira morte, registrada na China em 9 de janeiro, ele atravessou o mundo a bordo de nossos corpos que voam em aviões. Tornou-se onipresente no planeta, ainda que tão invisivel quanto certos deuses para olhos humanos". (El País, 25/03/2020)

Nesse trecho em (14), as expressões linguísticas antes destacadas mostram como o domínio SOBRENATURAL pode estruturar o domínio CORONAVÍRUS, a partir da metáfora VÍRUS É 
DIVINDADE. Nessa conceptualização, observamos que o coronavírus assume características de deuses, apresentando-se de forma não palpável, como um ser onipresente que pode estar em todos os lugares ao mesmo tempo e não é visto a olho nu, embora sua presença possa ser sentida. Assim sendo, como um deus onipotente, esse vírus segue sua trajetória com o poder de transformar a vida das pessoas, causando-lhes danos de diferentes níveis de intensidade, possibilitando inferir que CORONAVÍRUS É DEUS.

No corpus, verificamos, ainda, que parte do domínio NATUREZA é recuperado para a compreensão do domínio PANDEMIA. Como sabemos, a natureza é formada pelo mundo natural ou universo físico; desta forma, os fenômenos físicos, as paisagens e todos os seres vivos fazem parte dela. Em face desse acionamento, no exemplo que segue em (15), a pandemia é estruturada a partir de um fenômeno meteorológico, que nos permite acessar a metáfora DOENÇA É FENÔMENO NATURAL:

(15) “As pandemias começam restritas e passam por níveis de aceleração e crescimento, como se fossem uma bola de neve, que, durante o movimento de rolagem, ganha força até se tornar uma imensa avalanche". (UOL, 27/04/2020)

Em (15), observamos que, assim como uma avalanche, decorrente de um deslizamento de neve rápido, mas de grande proporção, que pode causar soterramentos e mortes, o vírus pode ser entendido como algo devastador, possibilitando inferir PANDEMIA É BOLA DE NEVE e PANDEMIA É AVALANCHE.

As seguintes ocorrências (16-17) são ainda geradas a partir do acionamento do domínio NATUREZA:

(16) "O vírus - e não as péssimas escolhas - será o culpado de todas as mazelas". (El País, 25/03/2020)

(17) "Governados por um maníaco, vivemos uma explosão no crescimento da contaminação por covid-19 e ninguém quer o vírus voltando a entrar pela sua porta depois de tanto esforço para tentar controlá-lo". (El País, 13/05/2020)

Sobre os vírus, o fato de não possuírem células em sua composição gerou discussões no campo das Ciências Biológicas, já que a célula é uma unidade estrutural e funcional de um ser com vida. Assim sendo, existe uma corrente que diz que eles não são vivos, pois, se não possuem células, não podem sobreviver sem um hospedeiro e existe uma outra que os considera seres vivos, pois podem sofrer mutações e se reproduzirem ${ }^{14}$. Apesar dessa discussão, as ocorrências (16) e (17) sugerem a metáfora VÍRUS É SER VIVO, a qual foi acionada através das expressões ser culpado e dos itens léxicos voltar e entrar. Desta forma, o vírus é compreendido como uma entidade que possui responsabilidade e executa ações, mas não necessariamente atividades humanas. Assim, é possível inferir: CORONAVÍRUS É SER VIVO, portanto, como uma entidade que ora pode ter responsabilidade por seus atos, ora pode, tão somente, se movimentar no espaço, como demonstram as ocorrências.

\footnotetext{
${ }^{14}$ Informações sobre a questão podem ser localizadas no artigo intitulado Vírus: vida e obra do mais intrigante dos seres. Disponível em Vírus: vida e obra do mais intrigante dos seres - FATONEWS. Acesso em 27 out. 2020.
} 
Ainda no domínio NATUREZA, mas acessando um saber que se adquire na experiência, o coronavírus é compreendido através da metáfora VÍRUS É FONTE DE CONHECIMENTO, tornando possível inferir que CORONAVÍRUS É EXPERIÊNCIA DE APRENDIZADO, conforme consta do seguinte exemplo:

(18) "Como aprender com o coronavírus a criar um futuro que não seja mais aniquilação?” (El País, 08/04/2020)

Nesse exemplo em (18), a expressão linguística, antes arrolada, nos faz acionar um conhecimento partilhado que temos de aprender com algo ou alguém. Embora nos artigos de opinião consultados tenha aparecido apenas uma ocorrência dessa metáfora, uma pesquisa no Google revela uma alta produtividade de usos da linguagem que instanciam essa conceptualização. Em uma procura feita por meio desse motor de busca da internet, no dia 18.09.2020, foram alcançados aproximadamente 93.800 .000 resultados, em 0,43 segundos.

Ainda vale chamar a atenção para o fato de essa conceptualização ser positiva em relação ao novo vírus, diferentemente das que até aqui foram apresentadas; isto porque, com a experiência pandêmica, o ser humano poderá se tornar melhor e poderá evitar sua própria destruição no devir do tempo.

O domínio ESPAÇO-TEMPORAL é também acionado para a conceptualização da pandemia e do (corona)vírus. Assim sendo, recorreu-se às metáforas DOENÇA/VÍRUS É MARCO para a produção de sentidos acerca desse problema de saúde e do seu agente causador. Essa compreensão deve-se ao conhecimento do uso de pedras para delimitação de espaços. Com isso, tornou-se possível entender a demarcação do tempo através da pandemia. Deste modo, as ocorrências de (19) a (24) possibilitam inferir PANDEMIA/(CORONA)VÍRUS É PONTO LIMITE DE TRAJETÓRIA ESPAÇO-TEMPORAL:

(19) "Quem fez oposição de fato, no Brasil pré-pandemia dos últimos anos, foram grupos identitários: mulheres, jovens, negros e indígenas". (El País, 08/04/2020)

(20) "É preciso, porém, fazer algo ainda mais difícil: lutar pelo futuro pós-vírus". (El País, 08/04/2020)

(21) "A tarefa é inadiável. Se não fizermos isso, o mundo pós-coronavírus será ainda mais brutal e o colapso climático se aprofundará”. (El País, 08/04/2020)

(22) "Quando se discute a construção de uma sociedade mais ecologicamente justa no pós-pandemia é necessário compreender que não haverá outro mundo possível [...]”. (El País, 02/06/2020)

(23) “Assim, no período pós-pandemia, ou mesmo durante a pandemia, já que não se sabe se ela acaba, todos os caminhos levam à direita neoliberal". (El País, 08/04/2020)

(24) "Além de nossa sobrevivência, o que disputamos neste momento é [...] que humanos seremos depois da pandemia”. (El País, 25/03/2020) 
Nessas ocorrências, o advérbio depois, os prefixos pós- e pré- e a preposição durante demarcam espaço-temporalmente a existência do mundo a partir do vírus pandêmico.

Por fim, o domínio-fonte ESPAÇO permite compreender o domínio-alvo PANDEMIA, através da metáfora DOENÇA É RECIPIENTE. Assim, a ocorrência (25) demonstra que a doença pandêmica está sendo vista como um local, no qual o planeta foi inserido. Foi possível compreender a pandemia em termos de uma área, porque a preposição em foi compreendida em temos indicativos de lugar, particularmente, um espaço que comporta algo.

(25) “O Brasil não só é um gigante com 210 milhões de habitantes, tanto vítimas quanto transmissores potenciais do novo coronavírus, como um gigante liderado pelo vilão número um do mundo em pandemia". (El País, 07/05/2020)

A metáfora VÍRUS É MATÉRIA EM MOVIMENTO viabiliza inferir VÍRUS É ENTIDADE. Desta forma, em (26), o vírus é tido como uma substância personificada que, por ser estável, pode praticar a ação desse movimentar no espaço, pois não há ainda as armas necessárias, isto é, as vacinas, para combater esse inimigo que se desloca de forma rápida para abater seu adversário, no caso, as pessoas acometidas de COVID-19:

(26) "[...] se trata de um vírus que se alastra rapidamente e ainda não há vacina para combatê-lo diretamente". (UOL, 27/04/2020)

Esse mesmo domínio é também recuperado nos excertos que instanciam a metáfora DOENÇA/VÍRUS É SUBSTÂNCIA DILATÁVEL e a seguir são expostos:

(27) "Essas são algumas questões para refletir sobre a atual pandemia e sua relação com as desigualdades e as indiferenças que se acentuaram e as que emergem com a expansão do coronavírus pelo mundo [...]”. (UOL, 27/04/2020)

(28) "Outros países que fazem fronteira com o país já expressaram sua preocupação com a expansão da covid-19 [...]”. (El País, 07/05/2020)

Em (27) e (28), o vírus e a doença são postos como uma matéria que tem a propriedade de dilatar-se, o que é possível compreender a partir dos acionamentos do sentido do item léxico expansão, entendido como dilatação de um corpo ou de um gás. Esses contextos viabilizam inferir que CORONAVÍRUS É ENTIDADE EM MOVIMENTO.

Antes de passar às considerações finais acerca do estudo empreendido, vale destacar, à guisa de síntese, que as principais metáforas identificadas no corpus são as que, a seguir, se encontram arroladas: DOENÇA É GUERRA; DOENÇA É FENÔMENO NATURAL; DOENÇA É RECIPIENTE; DOENÇA/VÍRUS É MARCO; VÍRUS É DIVINDADE; VÍRUS É SER VIVO; VÍRUS É ENTIDADE; VÍRUS É FONTE DE CONHECIMENTO e VÍRUS É MATÉRIA.

\section{Considerações finais}

Com a pesquisa empreendida, constatamos que distintos domínios foram acionados para a conceptualização da pandemia, da COVID-19 e do novo corona(vírus), resultando em diferentes metáforas e tornando possível inferências diversas. Além disso, averiguamos que, apesar de o 
corpus ter sido constituído por artigos de opinião, os três colunistas acionaram metáforas convencionais, a exemplo de DOENÇA É GUERRA e DOENÇA É FENÔMENO NATURAL, na construção desses textos. Este achado nos levou a concluir que, mesmo quando somos mais livres para expor nosso ponto de vista, a partir da nossa argumentação, as metáforas já cristalizadas no nosso sistema conceptual nos impõem uma perspectiva sobre um evento experienciado. E mesmo que essas metáforas viabilizem o uso de múltiplas expressões linguísticas que emergem no nosso discurso, o padrão conceptual metafórico impõe realidades, em decorrência dos enquadramentos feitos em outros momentos da história, responsáveis por gerar modos específicos de compreender o mundo, ofuscando formas distintas que poderiam ser mais eficientes para o tratamento de doenças, como a pandemia de COVID-19. Isto coaduna com a criação e a propagação de metáforas, no lastro temporal, por determinados grupos de poder e que podem ser expressas em variados domínios discursivos. Então, ainda que não nos encontremos em guerra, estamos aptos a fazer concessões, acatando, como já assinalado, que sejam feitos cortes nos nossos salários, afinal, quando estamos em estado de guerra, permitimos, assolados pelo medo, que sejam realizados atos que, possivelmente, não aceitaríamos em uma situação de vida normal. Um estudo de natureza cognitiva-sócio-histórica na flecha do tempo poderá ratificar ou não as reflexões aqui apresentadas, demonstrando como se mantém, variam e/ou se modificam as conceptualizações.

\section{Referências teóricas}

Almeida, A. A. D. (2018). A categorização à luz da Sociolinguística Cognitiva: diferentes organizações de mundos possíveis. In Ataíde, C. A. e Sousa, V. (Orgs.), Língua, texto e ensino: descrições e aplicações (pp. 269-284). Recife: Pipa Comunicação. Disponível em http://www.gelne.com.br/arquivos/L\%C3\%ADngua-texto-e-ensino\%20-20Gelne.pdf.

Almeida, A. A. D. (2020). Mo(vi)mentos da história e da ciência: a linguagem da pandemia sob a ótica da linguística cognitiva. Estudos linguísticos e literários, (69), 1-20. https://doi.org/10.9771/ell.v0i69.44286

Almeida, A. A. D. e Santos, E. S. dos (2020). Ciência, opinião e fake news em tempos de coronavírus: conceptualizações em memes sob a abordagem da Linguística Cognitiva. Pensares em Revista, (19), 56-76. https://doi.org/10.12957/pr.2020.52642.

Almeida, A. A. D. e Santos, E. S. dos (2019). O estudo do significado léxico em semântica sóciohistórico-cognitiva. Macabéa - Revista Eletrônica do Netlli, 8, (2), 136-157. Disponível em http://periodicos.urca.br/ojs/index.php/MacREN/article/download/1932/1411.

Almeida, A. A. D. e Santana, N.M. O. (2019). A semântica cognitiva sócio-histórico-cultural: questões epistemológicas. In Lopes, N.; Santos, E.; Carvalho, C., Língua e sociedade: diferentes perspectivas, fim comum (pp. 113-132). São Paulo: Blucher. Disponível em https://openaccess.blucher.com.br/article-list/9788580394016-434/list\#undefined.

Barcelona, A. (2009[1996]). O poder da metonímia, Cadernos de tradução - Linguística Cognitiva, (25), 7-24.

Batoréo, H. J. (2000). Expressão do espaço no português europeu. Contributo psicolingüístico para o estudo da linguagem e cognição. Lisboa: Fundação Caloust Gulbeikian/Fundação para a Ciência e a Tecnologia. 
Bezerra Ferreira, J. G. (2019). Fútbol es guerra: aproximación metafórica a titulares de El Mercurio. Árboles y Rizomas, 1 (2), 18-31. https://doi.org/10.35588/ayr.v1i2.3881

Bréal, M. Ensaio de Semântica: ciência das significações (1992[1987]). Aída Ferras et al.(Trad.). São Paulo: EDUC \& Pontes.

Eco, U. (2013). Da árvore ao labirinto: estudos históricos sobre o signo e a interpretação. Maurício Santana Dias (Trad.). Rio de Janeiro, RJ: Record.

Forceville, C. (2009). Metonymy in visual and audiovisual discourse. In Ventola, E. MoyaGuijarro, A. J. (Eds.). The world told and the world shown: issues in multisemiotics (pp. 56-74). Basingstoke: Palgrave Mac Millan.

Lakoff, G. e Johnson, M. (1980). Metaphors we live by. Chicago: The University of Chicago Press.

Lakoff, G. e Johnson, M. (1999). Philosophy in the flesh: the embodied mind and its challenge to western thought. New York: Basic Books.

Langacker, R. W. (1990). Cognitive Linguistics. BerlimlNew York: Mounton de Gruyter.

Morin, E. (2003). A cabeça bem-feita: repensar a reforma, reformar o pensamento. Trad. Eloá Jacobina. Rio de Janeiro: Bertrand.

Pérez, E. del C. (2018). La función de las metáforas en la construcción identitaria de Argentina. In Almeida, A. A. D. e Santos, E. S. dos. Linguística Cognitiva redes de conhecimento d'aquém e d'além-mar (pp. 53-70). Salvador: EDUFBA.

Santos, E. S. dos. A polissemia de vírus dos oitocentos ao tempo do novo coronavírus: um estudo sob a perspectiva da semântica cognitiva sócio-histórica. Estudos linguísticos e literários, (69), 339-365. https://doi.org/10.9771/ell.v0i69.44309

Talmy, L. (1988). Force dynamics in language and cognition. Cognitive Science, (12), 49-100. https://doi.org/10.1016/0364-0213(88)90008-0.

Vanin, A. A. (2016). A experiência do câncer de mama em palavras: notas sobre as possibilidades emergentes de um corpus temático. SCRIPTA, 20(40), 231-249. https://doi.org/10.5752/P.2358-3428.2016v20n40p231

\section{Referência do corpus}

Arruda, D. P. (2020). Coronavírus, desigualdade $e$ indiferença. Disponível em https://noticias.uol.com.br/opiniao/coluna/2020/04/27/opiniao-coronavirus-desigualdadee-indiferenca.htm

Brum, E. (2020). O vírus somos nós (ou uma parte de nós), El País, Brasil, 25 mar. 2020. Disponível em https://brasil.elpais.com/opiniao/2020-03-25/o-virus-somos-nos-ou-umaparte-de-nos.html

Brum, E. (2020). O futuro pós-coronavírus já está em disputa, El País, Brasil, 08 abr. 2020. Disponível em https://brasil.elpais.com/opiniao/2020-04-08/o-futuro-pos-coronavirus-jaesta-em-disputa.html.

Brum, E. (2020). O Brasil está matando o Brasil, El País, Brasil, 07 maio 2020. Disponível em https://brasil.elpais.com/opiniao/2020-05-07/o-brasil-esta-matando-o-brasil.html.

Brum, E. (2020). O nojo, El País, Brasil, 13 maio 2020. Disponível em https://brasil.elpais.com/opiniao/2020-05-13/o-nojo.html

Brum, E. (2020). Brasil sofre de fetiche da farda, El País, Brasil, 27 maio 2020. Disponível em https://brasil.elpais.com/opiniao/2020-05-27/brasil-sofre-de-fetiche-da-farda.html.

Brum, E. (2020). Tirem os joelhos brancos dos pescoços negros, El País, Brasil, 02 jun. 2020. Disponível em https://brasil.elpais.com/opiniao/2020-06-03/tirem-os-joelhos-brancosdos-pescocos-negros.html. 
Brum, E. (2020). Os manifestos estão brancos demais, El País, Brasil, 10 jun. 2020. Disponível em https://brasil.elpais.com/opiniao/2020-06-10/os-manifestos-estao-brancos-demais.html.

Brum, E. (2020). A marcha dos mortos, El País, Brasil, 07 ago. 2020. Disponível em https://brasil.elpais.com/brasil/2020-08-07/a-marcha-dos-mortos.html.

Brum, E. (2020). 7 de Setembro: morte, El País, Brasil, 03 set. 2020. Disponível em https://brasil.elpais.com/opiniao/2020-09-03/7-de-setembro-morte.html.

Brum, E. (2020). Os humanos que o vírus descobriu no Brasil, El País, Brasil, 16 set. 2020. Disponível em https://brasil.elpais.com/opiniao/2020-09-16/os-humanos-que-o-virusdescobriu-no-brasil.html.

Oyama, T. (2020). O último desserviço de Bolsonaro à nação, 03 set. 2020. Disponível em https://noticias.uol.com.br/colunas/thais-oyama/2020/09/03/o-ultimo-desservico-debolsonaro-a-nacao.htm. 